\title{
Protecting the Cuban Geological Heritage
}

\author{
M. Roberto Gutiérrez Domech*
}

Institute of Geology and Paleontology. Ministry of the Basic Industry, Cuba

\begin{abstract}
In order to know and evaluate the real condition of the sites of geological interest, or geosites, in the western Cuban territory, so as o propose measures to protect and preserve them, a methodology for diagnosis and a weighted classification of the patterns established were worked out.

Due to their importance as a Geological Heritage, the lithostratigraphic units (geological formations) recognized in the Stratigraphic Lexicon of Cuba were initially considered. These units are located as follows: 11 in Havana province; 21 in Havana City province; 37 in Pinar del Río province, and 11 in the Isle of Youth.

In the course of research and during field work, other 52 geosites were added due to their paleontologic, hydrogeologic and geomorphologic importance, as well as 7 sites of mining interest. Altogether, 159 sites were analyzed.
\end{abstract}

During field work, many geosites were found to be partially damaged, 15 out of them being severely affected by human action.

Some geosites have disappeared completely, e.g. the type sites of the geological Río Rancho and Majagua formations and most of the members of the Via Blanca formation, etc.

The National Commission for the Stratigraphic Lexicon is requested to find and designate different categories of stratotypes from 17 geologic formations and their members.

It is proposed that 17 geosites in Pinar del Río, Havana and Havana City provinces and in the Special Municipality of the Isle of Youth be designated Local Monuments and other 16 geosites be designated National Monuments.

Keywords: Geosites, geologic formations, karst landforms.

\section{INTRODUCTION}

The concept of Heritage or Inheritance is related to the material and spiritual wealth received through the legacy of relatives, friends or society and through the education and culture one acquires, but there are also heritage values arising out of one's own effort. In both concepts, the subjective and objective value of preservation for all generations is evident.

The heritage can therefore be material or immaterial and, when referring to natural wealth, the landscapes, objects and forms created by Nature can include both concepts.

Due to its nature, the natural heritage is necessarily collective; nevertheless, since it cannot be framed or protected like an object, it requires awareness, education and legislation to protect it.

Research done to learn about the geologic structure of regions and countries all over the world, for the sake of economic exploitation of their natural resources, has led to knowing very representative and strange geological sequences; well-preserved crystallizations; and other geological bodies that are part of this natural heritage and should be preserved as with a measurement standard. Such research has entailed both expenses and the sacrifice of many generations, and the researched sites can be key to consolidate the results attained, to make the comparisons needed for continuous progression of

*Address correspondence to this author at the Institute of Geology and Paleontology. Ministry of the Basic Industry, Cuba; Tel: 537881 0651; Fax: 537696 7004; E-mail: rgdomech@igp.gms.minbas.cu knowledge on geological subjects. These geosites are patterns the conservation of which is unavoidable.

At the international level, the following are considered to be geological heritage:

- Type sites and stratotypes of litho- and biostratigraphic units;

- Holotypes and paratypes of fossil animal and plant species;

- Fossil deposits where holotypes and paratypes have been reported;

- $\quad$ Recognized ores and mines that are representative of important exploitation;

- Drilling cores and surface samples of important geologic sites;

- Geologic structures of interest;

- $\quad$ Original reports either drafted by important scientists in the geological field or related to the finding of mines, oil deposits, important fossils; mineralmedicinal water springs, etc;

- Other goods created out of one's own effort in the interest of geologic work.

UNESCO has created a register on Geological Heritage round the world and recognized its importance by declaring 2008-2009 as "Year of Planet Earth". 
The National Heritage Commission of Cuba has learned about the goals of this research project and agrees on its projection and objectives, so the commission should state its opinion on any proposals made to it.

The methodology used to categorize the chosen geosites was debated in several scenarios, e.g. two international congresses: the $2^{\text {nd }}$ Convention on Earth Sciences and the $6^{\text {th }}$ Convention on Environment and Development, where it was favorably met since it provides tools that are not known in the world.

In fulfilling this project, there is no intention of encompassing all geosites of heritage interest in western Cuba, since the geosites presented herein correspond only to those known by the authors or to those estimated to be more prone to be affected [1].

\section{METHODOLOGY USED TO EVALUATE GEOSITES: PATTERNS TO BE CONSIDERED}

1) Physical condition of the geosite. Whether the area is free from weeds, solid or liquid waste, or whether it is being used for non-research purposes.

- $\quad$ Appropriate Free from weeds, waste, or any other circumstances disturbing or damaging the area

- Scarcely appropriate: It is slightly covered with weeds; it temporarily and slightly contains waste of elements causing no definitive harm, or it is being used for non-research purposes.

- Inappropriate: It is extensively covered with weeds or it is in a farming area. It is being used for solid or liquid waste disposal in or through it. It is permanently occupied by any building.

\section{2) Representativeness and scientific value}

- High. In case it is an original site, a lectostratotype, a neostratotype or a geosite where macrofossil and microfossil holotypes have been described or large populations of such fossil species have been found, so these sites truly represent a given geological era or a specific geological development. Also, sites featuring landforms of singular, distinctive characteristics.

- Average. In case of parastratotypes and other representative outcrops, but there are similar or equivalent formations elsewhere that are in better conditions. Sites where typical fossil flora or fauna species have been described, but they are not type sites. This category can also comprise sites that feature forms and structures evidencing representative processes of a specific moment of geological development.

3) Historical value

- High. If it is related to the work of the predecessors or represents an inflection point in the development of geosciences.

- $\quad$ Average. If it only represents a geosite where a rock or bioestratigraphic unit has been described, a species, genus or group of fossils has been identified, or the existence of a geological phenomenon has been proven.

4) Didactic importance for teaching or promoting geosciences
- High. It contains, practically in itself, what is to be emphasized or several phenomena that altogether define a given structure or phenomenon that is to be explained, or it clearly shows the fossil fauna and/or flora that identifies an age or a process.

- $\quad$ Average. If the geological forms and processes are not so representative, so other means should be used to explain a phenomenon or a structure.

5) Esthetic value for teaching and tourism

- High. If it comprises spectacular structures, crystallizations, dislocations, etc that can be shown to qualified or unqualified visitors and can attract their attention and interest.

- $\quad$ Low. If they lack spectacular forms that are attractive to the newcomer visitor.

6) Rareness. Because of the difficulty to find any geosite with these characteristics.

- $\quad$ Outstanding. If the phenomenon or form existing in the geosite is not known elsewhere in the national territory or in the region or in the world.

- $\quad$ Scarce. If the geologic fact featured in the site is rarely found in the national territory or abroad, according to the level of knowledge of the project staff and the literature available.

- Common. If other similar sites are known in the national territory and abroad.

7) Unrepeatability. It has to do with rareness but also with the disturbances or disappearances that may have occurred in similar geosites, which are irrecoverable.

- Unrepeatable. If it is the only place where the rock or biostratigraphic unit has been described, if it is the only site where a given species has been found, or if the other known geosites have been damaged or destroyed irrecoverably.

- $\quad$ Repeatable. If there are other places that have similar characteristics and represent equal situations, structures, forms or phenomena defining them as important geosites.

8) Vulnerability. This pattern is related to the physical condition of the geosite

- Highly vulnerable. If the site is highly exposed to the human and natural actions and its characteristics and conditions evince that it should be protected from both agents by way of a special measure.

- Vulnerable: If it is a site exposed to human or natural actions and should be protected from any of these agents.

- Scarcely vulnerable. If the condition or physical characteristics of the site are good and the site is protected from the human action or can be protected through simple measures.

9) Size. According to the area it encompasses.

- Large. If its area covers more than one hectare or is more than $500 \mathrm{~m}$ long, in the case of an area where a geologic formation has been described. In the case of 
the site of a holotype, the whole area must be considered.

- $\quad$ Average. If it covers less than one hectare and/or is less than $500 \mathrm{~m}$ and more than $100 \mathrm{~m}$ long.

- Small. If it is less than $100 \mathrm{~m}$ long or $100 \mathrm{~m}^{2}$ (if it is an outcrop).

10) Accessibility. According to the possibilities for access.

- Easily accessible. If there is a road for common vehicles to the geosite.

- Accessible. If there are roads for draft animals or persons to the geosite

- Scarcely accessible. If there are only tracks or twisting paths to the geosite

- Inaccessible. If there are no roads to the geosite and they have to be opened across the field in order to visit the geosite.

\section{Consideration of the Patterns}

The patterns of representativeness and scientific value, historical value, didactic importance, esthetic value, rareness and unrepeatability represent the real scientific importance of the geosite and the reasons why it should be considered a heritage or geological heritage, while the patterns of physical condition, vulnerability, accessibility and size carry the most weight during diagnosis aimed at evaluating to what degree the site should be and for the proposals to be made in order to preserve the site. Therefore, on the Table 1 of considered values made on the basis of 100-point scoring, the latter patterns receive the highest score.

\section{DESCRIPTION OF SOME OF THE MOST IMPORTANT GEOSITES}

Author visited 139 sites of interest to the geological heritage, but it is impossible to describe them all in this article, so the author decided to show those sites that best characterize the Cuban geology (Fig. 1).

In addition to diagnosing the condition of the visited geosites, some stratotypes were found to be in a critical condition, so the National Commission for the Stratigraphic Lexicon was requested to designate new stratotypes for the following geological formations: Jabaco, Guanajay, Martín Mesa, and Güines in Havana province [2]; Capdevila, Consuelo, Punta Brava, and Santa María del Rosario in Havana City province [3]; as well as the members of the Via Blanca formation in that territory.

The identification of new stratotypes for the following formations: Río Rancho, Majagua and Cacarajícara in Pinar del Río province is proposed [4].

In the territory of the Isle of Youth municipality, the designation of a new stratotype for the Agua Santa formation [5].

\section{Pinar Del Río Province}

The following are proposed as Local Monuments (Heritage): Poza Redonda, Poza de Juan Claro, Laguna del Valle de San Juan, Manantial de Mal Paso, and Cayos de San Felipe geosites as well as the type sites of Pons, Arroyo
Cangre, Cacarajícara, Loma Candela and El Sábalo formations and the informal unit of Old olistostrome.

Table 1. Considered Values Made on the Basis of 100-Point Scoring, the Latter Patterns Receive the Highest Score

\begin{tabular}{|c|c|c|c|}
\hline \# & Pattern & Classification & Score \\
\hline \multirow{3}{*}{1} & \multirow{3}{*}{$\begin{array}{l}\text { Physical condition of } \\
\text { the geosite }\end{array}$} & Appropriate & 3 \\
\hline & & Scarcely appropriate & 4 \\
\hline & & Inappropriate & 5 \\
\hline \multirow{2}{*}{2} & \multirow{2}{*}{$\begin{array}{l}\text { Representativeness and } \\
\text { scientific value }\end{array}$} & High & 15 \\
\hline & & Average & 10 \\
\hline \multirow{2}{*}{3} & \multirow{2}{*}{ Historical value } & High & 10 \\
\hline & & Average & 7 \\
\hline \multirow{2}{*}{4} & \multirow{2}{*}{ Didactic importance } & High & 12 \\
\hline & & Average & 8 \\
\hline \multirow{2}{*}{5} & \multirow{2}{*}{ Esthetic value } & High & 10 \\
\hline & & Low & 7 \\
\hline \multirow{3}{*}{6} & \multirow{3}{*}{ Rareness } & Outstanding & 12 \\
\hline & & Scarce & 8 \\
\hline & & Common & 4 \\
\hline \multirow{2}{*}{7} & \multirow{2}{*}{ Unrepeatability } & unrepeatable & 12 \\
\hline & & Repeatable & 8 \\
\hline \multirow{3}{*}{8} & \multirow{3}{*}{ Vulnerability } & Highly vulnerable & 12 \\
\hline & & Vulnerable & 8 \\
\hline & & Scarcely vulnerable & 2 \\
\hline \multirow{3}{*}{9} & \multirow{3}{*}{ Size } & Large & 2 \\
\hline & & Average & 4 \\
\hline & & Small & 6 \\
\hline \multirow{4}{*}{10} & \multirow{4}{*}{ Accessibility } & Easily accessible & 6 \\
\hline & & Accessible & 5 \\
\hline & & Scarcely accessible & 4 \\
\hline & & Inaccessible & 2 \\
\hline
\end{tabular}

When scoring from 85 to 100 points, geosites are considered class A and should be given more protection and, if possible, a heritage, local or national category.

When scoring from 70 to 84 points, geosites are considered class B, and a management method and, if feasible, a local heritage category should be established for them.

When scoring from 50 to 69 points, geosites are regarded as class $\mathrm{C}$ and should receive some treatment by the local authorities.

There should be adequate signage in all sites that are important to the geological inheritance.

The following are proposed to be considered National Monuments (Heritage): Majaguas-Cantera and Fuentes, Constantino and Los Perdidos cave systems; Hoyo de Potrerito, Sierra Derrumbada Natural Bridge (so far, it was unknown to science) and Puerta del Ancón (Ancón karstic canyon) geographic sites; GEDA and Cumpleaños caves; as well as the outcrop dating from the K-T boundary in El Moncada and the holostratotype of the Ancón formation. 

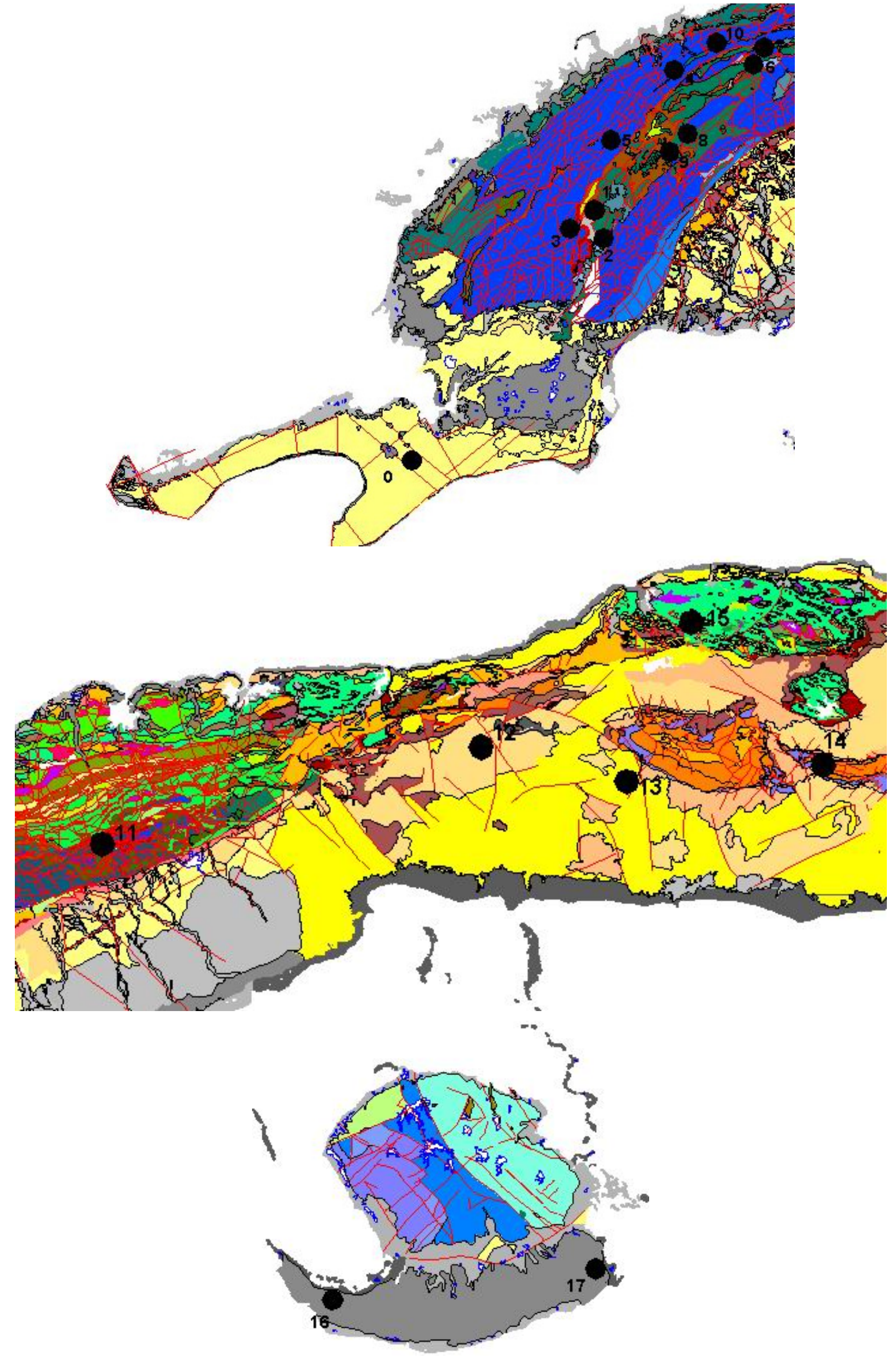


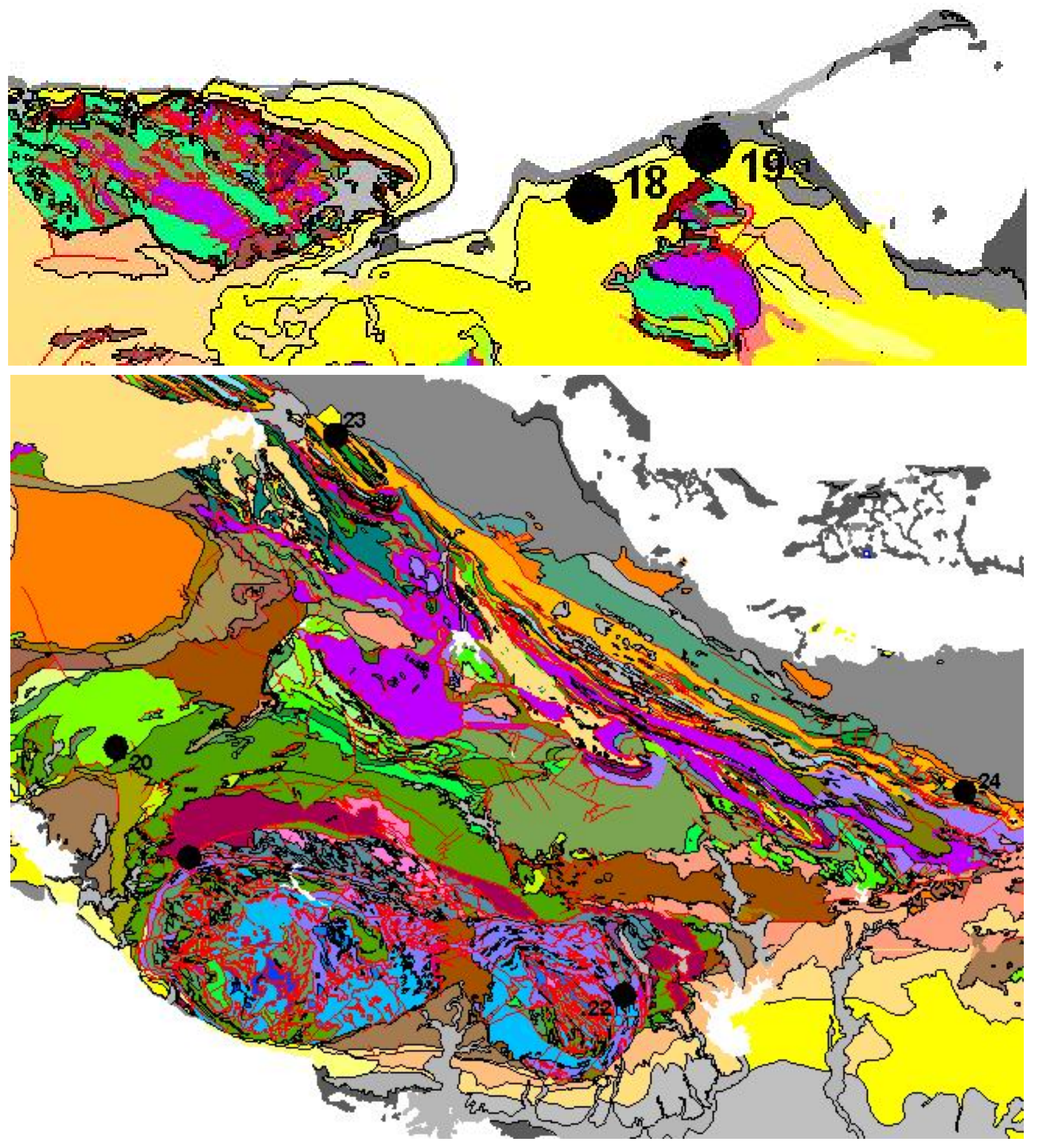




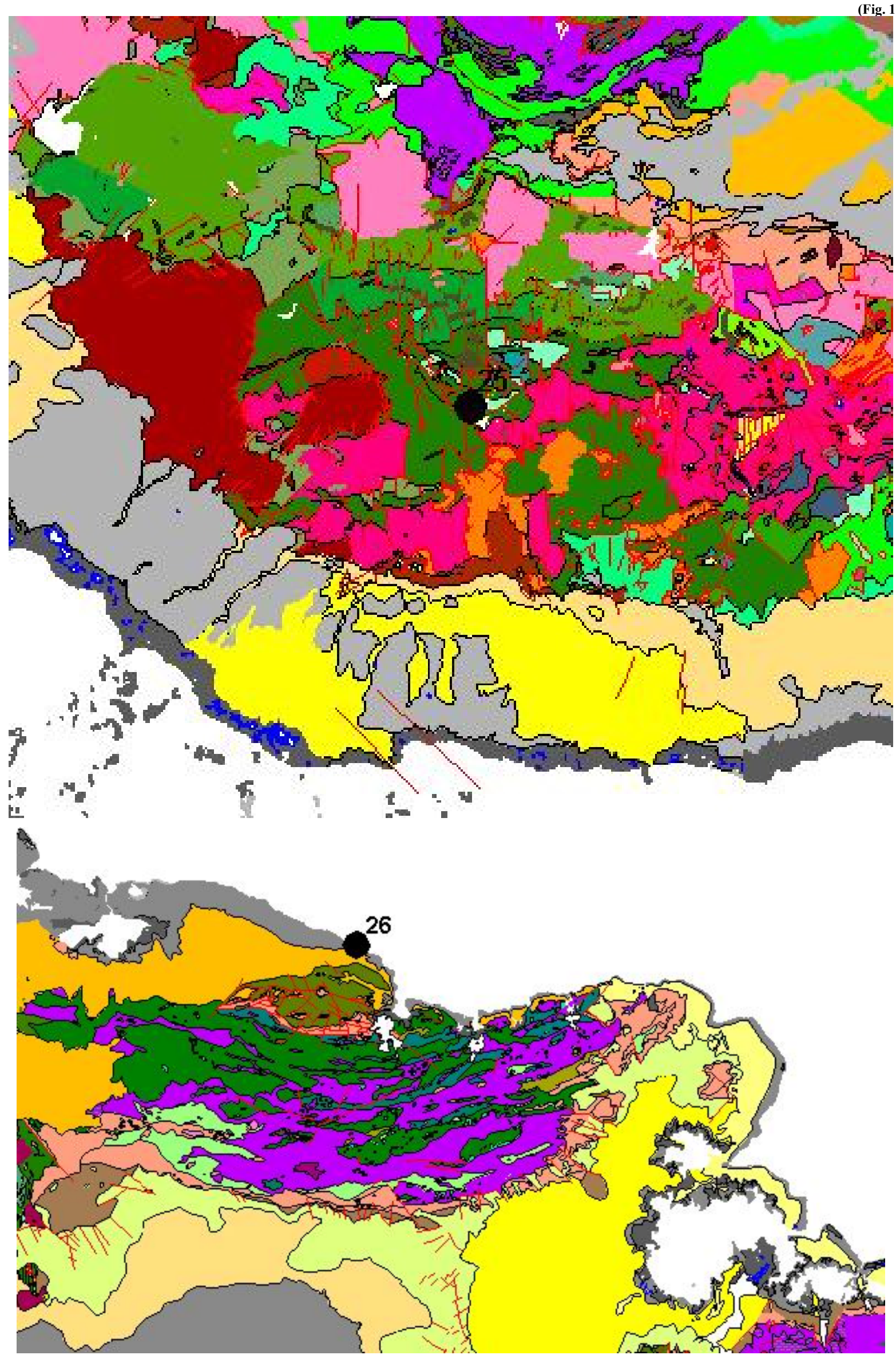




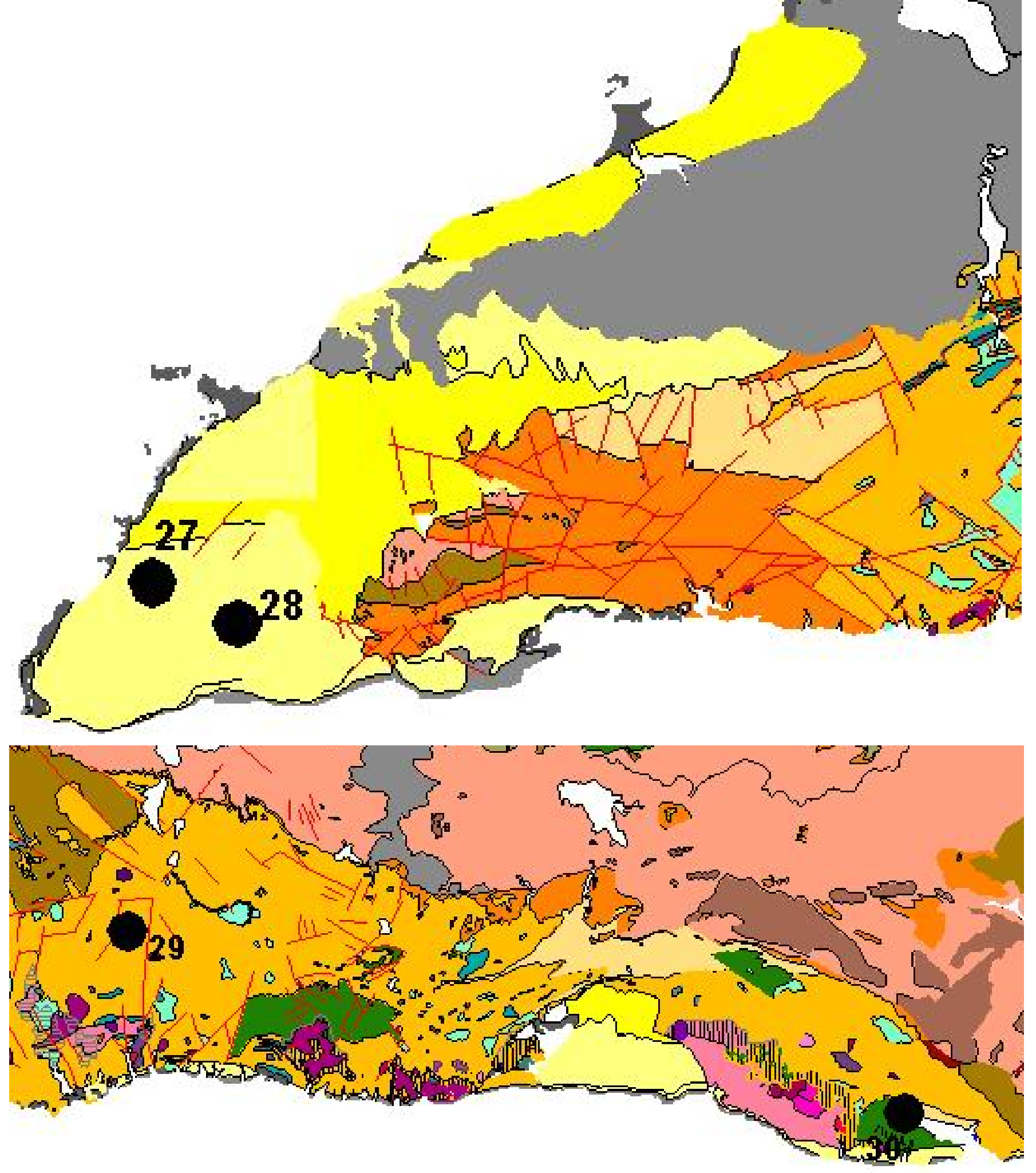


(Fig. 1) contd.....

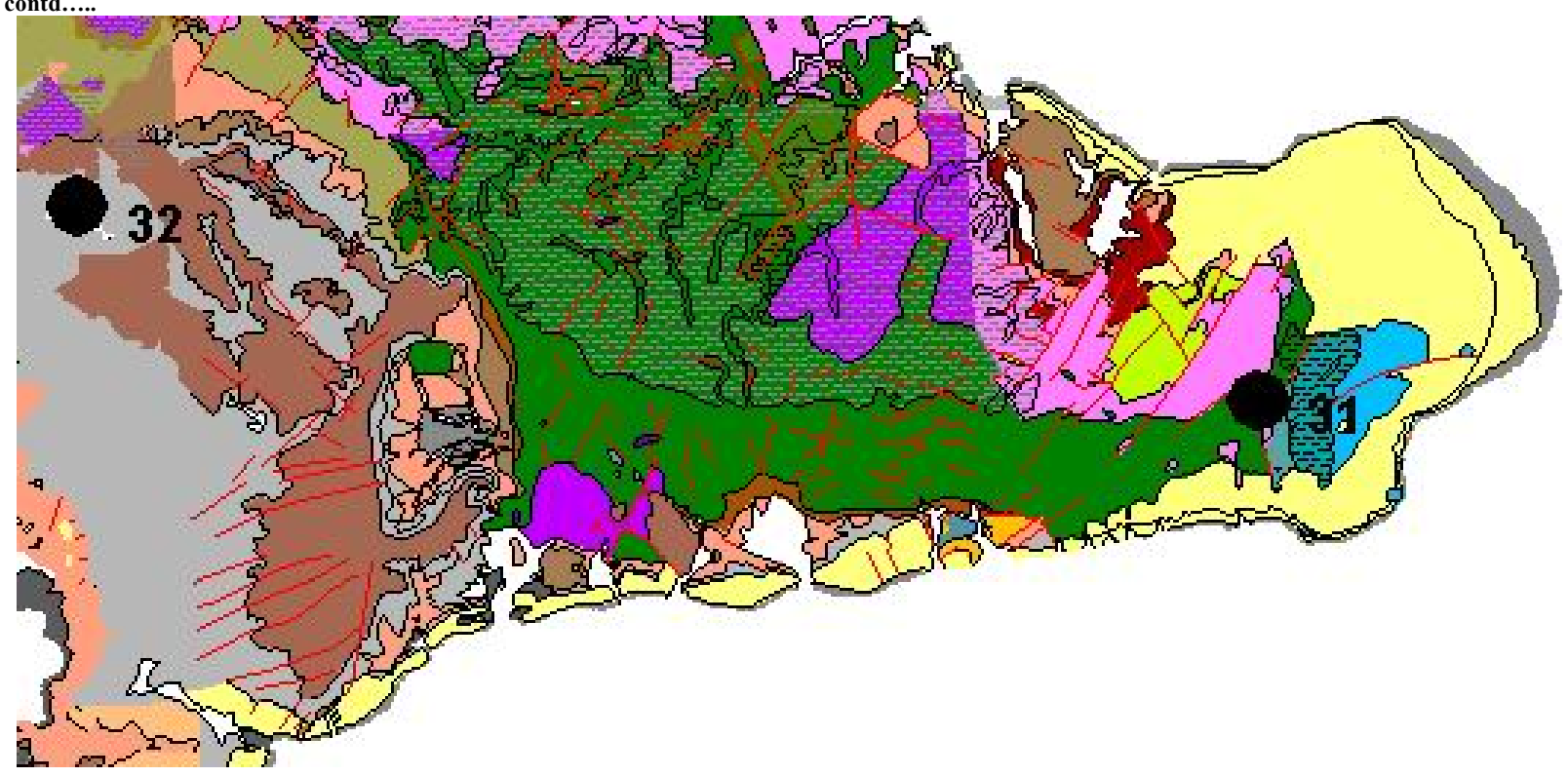

Fig. (1). Geological Map of Cuba, showing some of the more interesting geosites of the territory according to geology, palaeontology, stratigraphy and speleology importance.

0. Laguna del valle de San Juan (= San Juan valley lagoon).

1. Hoyo de Potrerito (= Potrerito hole).

2. Sistema Cavernario Majaguas Cantera (= Majaguas Cantera cavernary system $)^{1}$

3. Sistema Cavernario Fuentes (= Fuentes cavernary system $)^{1}$.

4. Sistema Cavernario Constantino (= Constantino cavernary system)

5. Puente Natural Sierra Derrumbada (= Sierra Derrumbada Natural Bridge).

6. Puerta del Ancón (= Ancon canyon).

7. Cueva GEDA (=GEDA cave) Cueva del Cumpleaños (Birthday cave).

8. Afloramiento del límite K/T en El Moncada (=El Moncada K/T Boundary outcrop).

9. Gran Caverna de Santo Tomas (=Santo Tomas Great Cavern) ${ }^{2}$.

10. Holoestratotipo Formación Ancón (=Ancon formation holostratotype).

11. Sistema Cavernario Los Perdidos (Los Perdidos Cavernary System).

12. Cueva de Paredones (= Paredones cave).

13. Cueva del Túnel (= El Tunel cave).

14. Cueva y Dolina de Loma Candela (= Cave and sinkhole of Loma Candela $)^{1}$.

15. Holoestratotipo de la Formación Peñalver (= Peñalver Formation holostratotype).

16. Holoestratotipo de la Formación Cocodrilo (= Cocodrilo Formation holostratotype).

17. Cueva de Punta del Este (= Punta del Este Cave) ${ }^{2}$.

18. Cueva de Bellamar (= Bellamar Cave $)^{2}$.

19. Cueva de Santa Catalina (= Santa Catalina Cave $)^{3}$.

20. Baños de Ciego Montero (= Ciego Montero bathing place).

21. Cueva de Martín Infierno (= Martín Infierno Cave).

22. Hornos de Cal (= Limekiln quarry and caves).

23. Mogotes de Jumagua (= Jumagua karst Hills).

24. Abra de Boquerones (= Boquerones canyon).

25. Bosque Petrificado del Chorrillo (= Petrified foresto of El Chorrillo).

26. Cueva Tanque Azul (= Tanque Azul submerge cave).

27. Cueva del Guafe (= El Guafe "indian" cave).

28. Cueva de Morlotte (= Morlotte shaft).

29. Cueva Jíbara (= Jíbara Pit).

30. Los Motilones.

31. Cueva de La Patana (= La Patana "indian" Cave).

32. Cueva del Campanario (= El Campanario "aqueduct" Cave).

\footnotetext{
${ }^{1}$ Local patrimony

${ }^{2}$ National patrimony
}

\footnotetext{
${ }^{3}$ Requested as National Patrimony
} 


\section{Laguna Del Valle De San Juan (Lagoon in San Juan Valley)}

It is a typical cenote or flooded karstic sinkhole, like the famous cenotes related to both Maya culture and the development of karst in the Yucatan Peninsula. It is some $110 \mathrm{~m}$ long and $25 \mathrm{~m}$ deep, which makes it the deepest one in the region.

Its shape is circular, with rocky banks made up of limestone, probably of the Güines formation from the Miocene, which makes it different from the so-called casimbas (also cenotes) in Zapata Swamp that have received a greater tectonic influence and have an elongate shape; it also differs from Poza Redonda (Round Pool) and Poza de Juan Claro (Juan Claro Pool) - which are in said peninsula too - as it lacks underwater galleries.

There is incipient karren in the surroundings, as well as spots made up of "patches" of calcrete or karst pavement. The karren hollows are occupied by red ferritic soils (or red rendzina), on which abundant shrub vegetation grows.

Laguna del valle de San Juan is in the easternmost fringes of Guanahacabibes Peninsula, next to the road leading from La Bajada to Sandino, and close to some houses, its vulnerability therefore being high. This is why it is proposed that the site be protected by the nearby station of ECOVIDA (a protected area enterprise located in La Bajada), an environmental education plan targeting the nearby community be developed, and the site be declared Local Monument.

During the diagnosis, this site scored 80 points and was categorized as B (Fig. 2).

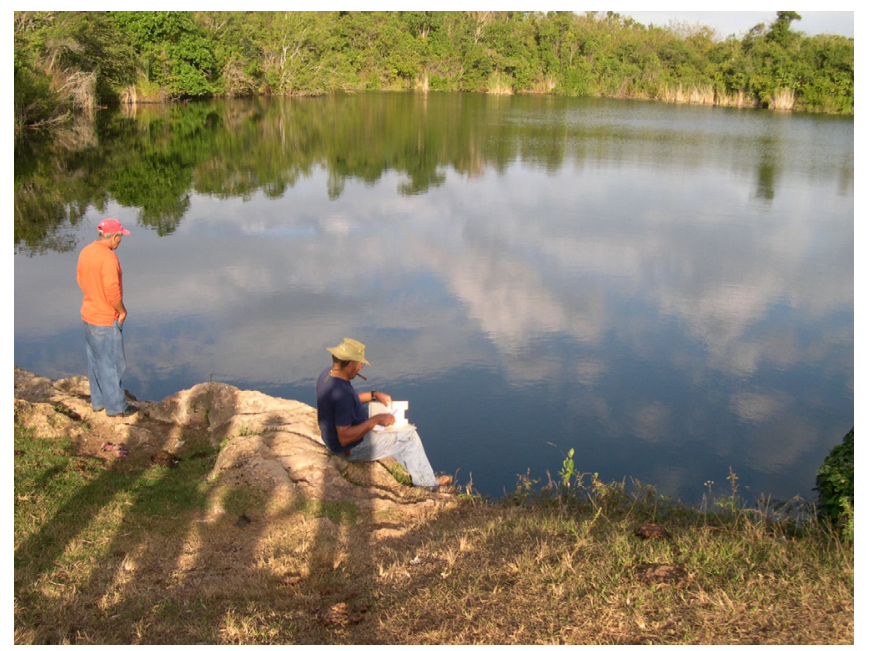

Fig. (2). Laguna del Valle de San Juan (San Juan valley “cenote”) type karst sinkhole in Guanahacabibes península.

A sign for this geosite should read:

\author{
LAGUNA DEL VALLE DE SAN JUAN \\ LOCAL MONUMENT \\ TYPICAL KARSTIC CENOTE \\ DO NOT DROP LITTER INTO ITS WATERS \\ PROTECT IT
}

\section{Majaguas-Cantera Cave System}

Stretching over $35 \mathrm{~km}$, this underwater-gallery system was excavated by Majaguas and Las Canteras creeks, which have their source in Alturas de Pizarras del Sur, to the south of the hummock-made Sierra de San Carlos. These two creeks cross the cave system, combine their courses inland, and become a tributary to Cuyaguateje river after crossing Bordallo inlet, in Luis Lazo (San Carlos) Valley [6] (Fig. 3).

The cavern system is made up of at least 6 different, mostly interconnected levels corresponding to:

1. Course 1 or The Key (which should rather be called The Keyhole), which is the current underground course of said streams and their resulting end (Majaguas river) that comes out (Fig. 4) through a main outpouring and, during heavy rainfall, through a secondary outpouring (Cueva Fría (Cold Cave)) toward Bordallo inlet in San Carlos valley.

2. $20^{\text {th }}$ Anniversary Cave, with wide galleries and chambers stretching over two levels to reach Majaguas creek sinkhole. This cavern includes the Salón de los Pajaros (Birds Chamber), which is one of the largest chambers all over the world: over $300 \mathrm{~m}$ long, $200 \mathrm{~m}$ wide and over $150 \mathrm{~m}$ high, and allows access to the top of the mountain. There are ponds that collect dripping water even during the worst droughts (Fig. 5).

3. Cueva de las Dos Anas (Two Anas Cave) that acts like a trop plain in times of heavy rainfall or storms, where remains of Cuban fossil mammals have been discovered, e.g. the sacrum of an edentate of Acratocnus genus. Here are ponds constituting important reservoirs for local water supply and irrigation in times of drought.

4. Cueva de Dos Hermanos (Two Brothers Cave). A wonderful cave with unbelievable speleothems, the entrance of which is some $50 \mathrm{~m}$ above the level of the valley, in Hoyo de los Helechos, a steep-walled sinkhole about $700 \mathrm{~m}$ long that has formed in a section of the central-north mountain range.

5. Cueva Chefa (Chefa Cave). A cave that passes, almost rectilinearly, through a "tower" of Sierra de San Carlos, more than $70 \mathrm{~m}$ high, from Hoyo de los Helechos; it is a watchtower to look at Luis Lazo valley. Remains of Megalocnus rodens and other edentates from the Pleistocene have been found here.

6. Cueva Julio Verne (Jules Verne Cave). It was excavated in the uppermost level of the mountain range. There are remains of very well preserved vertebrates from the Quaternary as well as remains of a terrestrial turtle. Also, the system includes the sectors -they are currently disconnected- of the Amadea creek (Amadea cave) and Herrería cave, which are now separated by the karstic cove known as Abra de la Trinchera (Trench Cove), through which the road from Pinar del Río to Guane (Luis Lazo road) runs. 

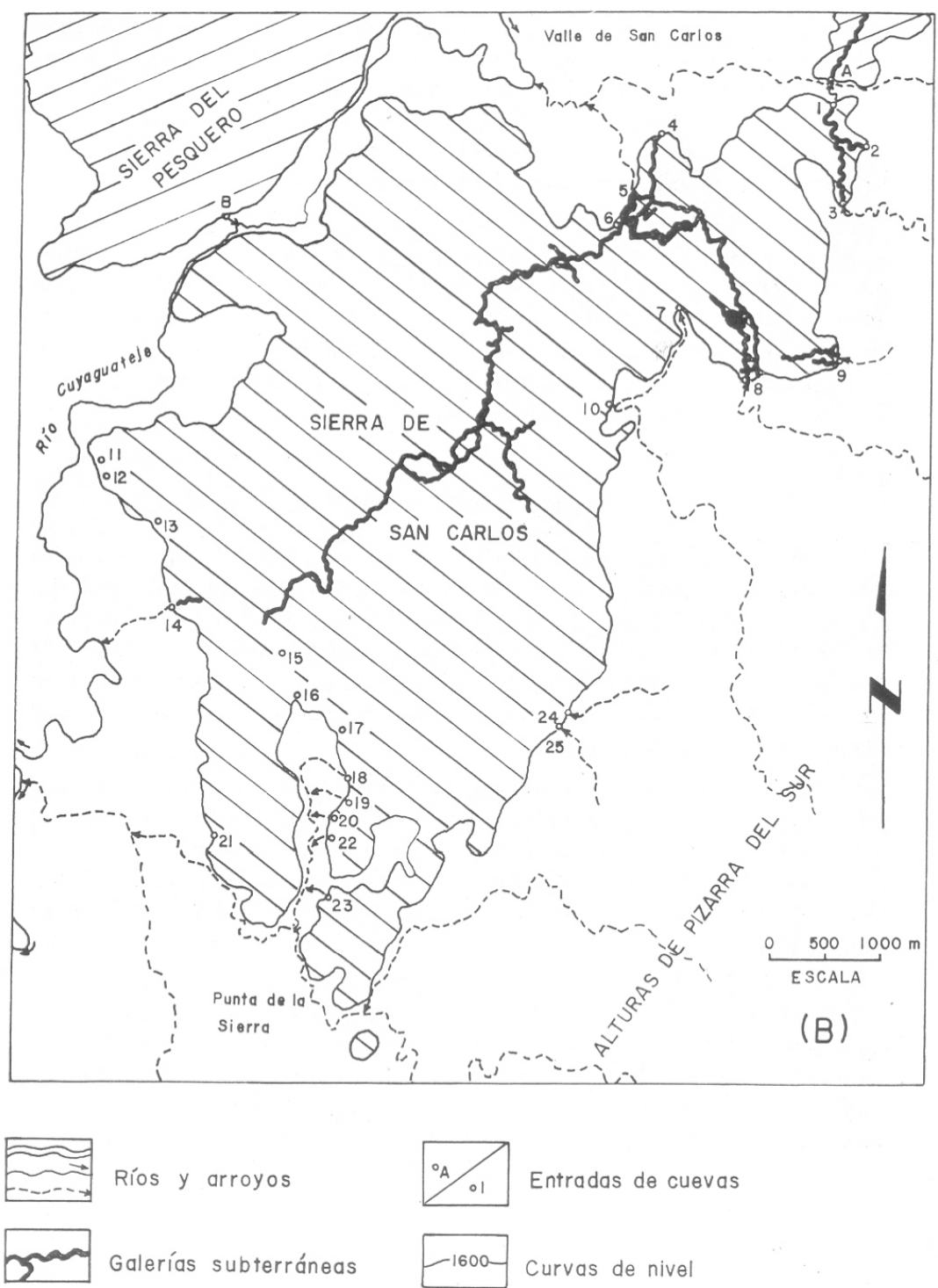

Ríos y arroyos

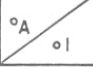

Entradas de cuevas

Galerías subterráneas

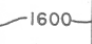

Curvas de nivel

Fig. (3). Geomorphological écheme from San Carlos valley, where Majaguas-Canteras system is located.

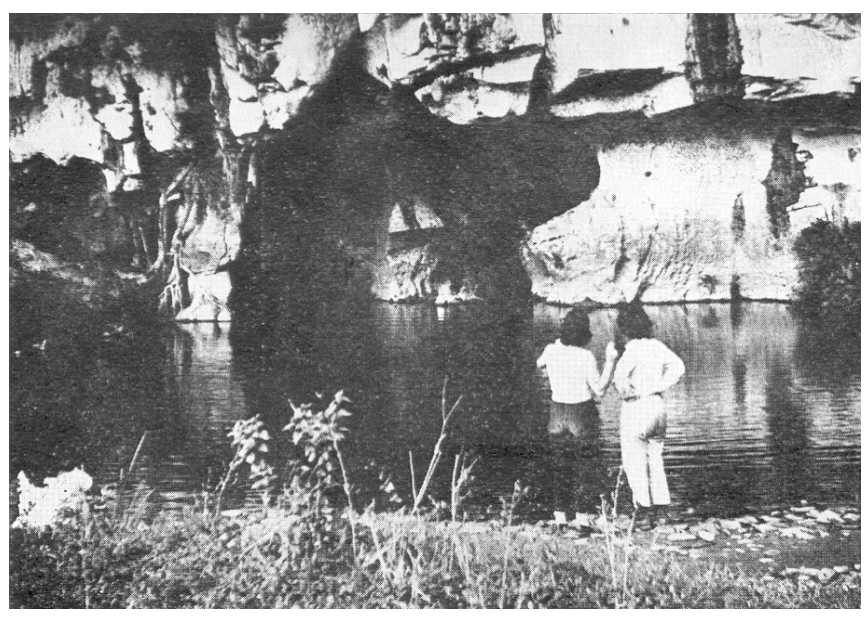

Fig. (4). Entrance of Majaguas and Canteras river underground common course. The entrance is called the Key, but most be called the Keyhole. The main river gallery is about $5 \mathrm{~km}$ long.

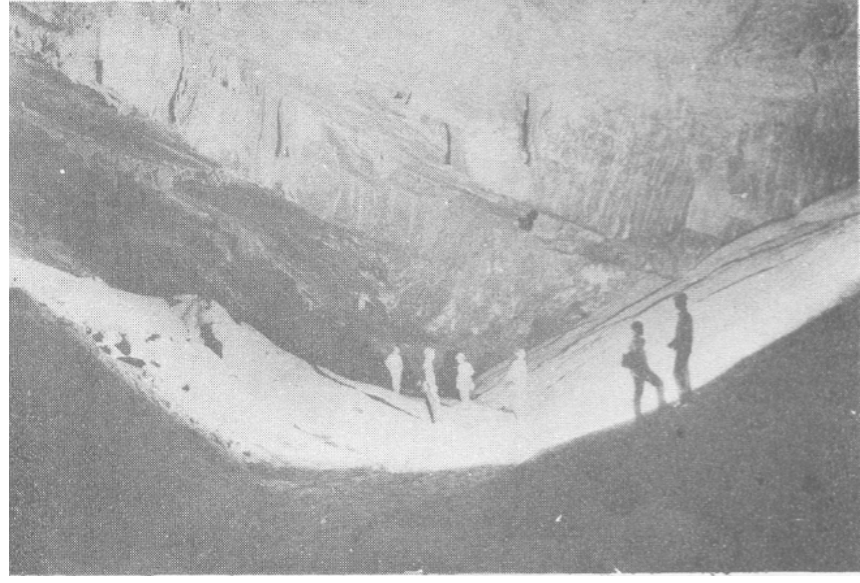

Fig. (5). This XX Anniversy Cave. All these 3 photos are from the first expeditions. The Chamber of the Birds, that is not in the photo but it's a part of the cave is one of the bigger in the world. 
These caves have been excavated in limestone of Guasasa formation from the Upper Jurassic, the limestone being massive or stratified in thick layers and strongly faulted.

It has been proposed that the authorities of the municipality should appoint staff to work as guardians in order to protect the most exposed sections such as the Salón del Campamento (Campsite Chamber) in Cueva de los Gigantes (Giants Cave), which is its natural entrance through Bordallo inlet and where religious groups have painted signs and school activities have taken place without taking due care once such activities are concluded (Fig. 6).

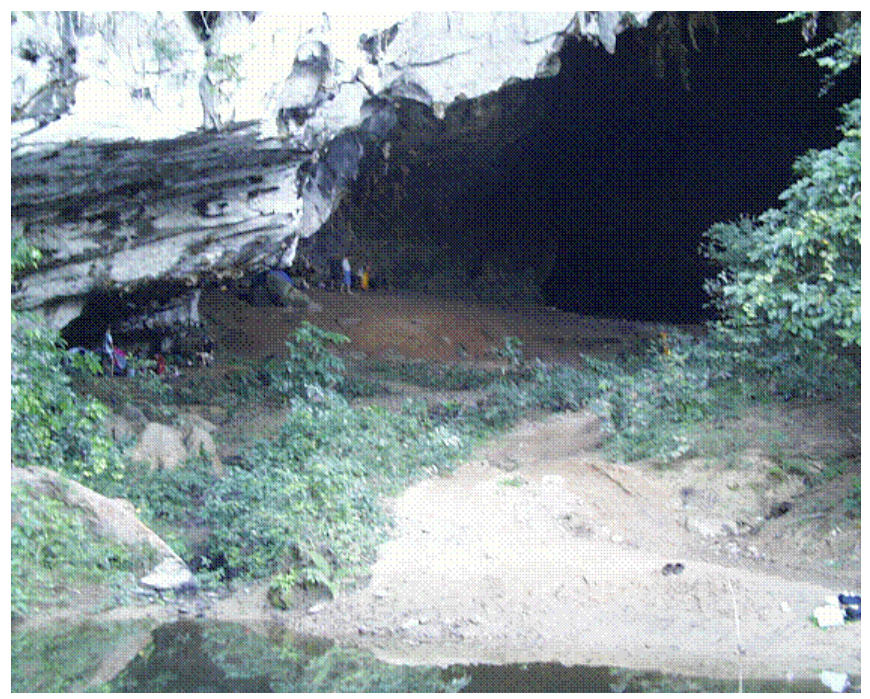

Fig. (6). Campament Chamber, Cave of the Giants, third level of Majaguas-Cantera System.

Due to its great economic and scientific importance, this geosite has reached category $\mathrm{A}$ and is proposed as a National Monument.

An adequate sign would read like this:

\section{MAJAGUAS-CANTERA CAVE SYSTEM NATIONAL MONUMENT UNDERGROUND COURSE OF MAJAGUAS AND LAS CANTERAS CREEKS MORE THAN 35 KM OF GALLERIES DO NOT DROP LITTER, DO NOT PAINT THE WALLS KEEP ONLY THE PHOTOS YOU TAKE}

\section{Outcrop from the K-T boundary in El Moncada}

The existence of evidence proving that a meteorite hit the Earth 65 million years ago -a collision that brought about massive extinction of the vertebrate and invertebrate fauna typical of the Mesozoic era- has been the main purpose of several projects developed by Cuban and foreign institutions in Cuba.

The olistostrome appearing in an outcrop along the Viñales-Pons road, at the entrance of El Moncada location, $17 \mathrm{~km}$ west of Viñales, is one the sites where traces of iridium, mineral spheres and other pieces of evidence can be found in the Cuban territory.

The outcrop is very exposed and material has eventually been extracted from the slope, probably for building purposes. Besides, the outcrop is at the mercy of any road maintenance actions that may be taken.

This geosite has been visited by international expeditions and during events of like nature, so it has become renowned worldwide. Due to its scientific and didactic importance, since its lithology is typical of these geological bodies, it scored 89 points in the diagnosis and was classified as a category-A geosite.

It is proposed as a National Monument, with the recommendation that the main area of the outcrop be demarcated with a surrounding fence and a sign be placed with the following information:

\section{MONCADA OLISTOSTROME NATIONAL MONUMENT INTERNATIONAL-CLASS GEOSITE REPRESENTATIVE OF THE CRETACEOUS/TERTIARY (K-T BOUNDARY) PROTECT IT}

\section{GEDA Cave ${ }^{4}$}

This extraordinary geosite opens up in the west slope of Sierra de Guasasa, several tenths of meters above the surface of San Vicente valley. It is a perfect example of neotectonic dynamics and the glacieustatic movements that brought about the alternate rise and fall of the basic level of waters during the Quaternary.

The cave was excavated in Sierra de Guasasa, at the level of the valley, by a stream no longer existing; the cave rose rapidly together with the mountain range, until it reached its current altitude, as proved by the morphology of its main gallery, the passages to different levels, and the sediments and concretions covering the floor.

In several chambers and galleries, complete remains without any displacements- of sloths, rodents, and other mammals have been found, which shows the abundance of fauna in that region during the Upper Pleistocene and the Holocene and reaffirms the relatively quick ascent of the set of galleries, since otherwise the river water would have scattered the dead bodies.

In the galleries, there is abundant decoration of ceiling, floor and wall speleothems of different shapes and colors, with outstanding speleolothems made up of gypsum and aragonite.

Some sections of the cave were harmed subsequently, as they were nearly severed by a fault that transversely cuts the cave profile and affects the whole hummock-made mountain range.

\footnotetext{
4 GEDA is the acronym of the Grupo Espeleológico de Deportes $y$ Aventuras (Speleological Group for Sports and Adventures) that discovered the cave.
} 
Though its access is very difficult, the cave has rather frequently been visited by local climbers who, acting as guides, lead tourist to admire its richness.

Due to its characteristics, this site ranks A, with 90 points, and it is proposed as a National Monument. It is recommended that access to the site be restricted and controlled by park rangers and a trespassing-preventing iron gate be built, so as to avoid destruction of the paleontological and speleological treasures existing there, such destruction having already occurred, even unintentionally, because of their arrangement within the cavity (Fig. 7).

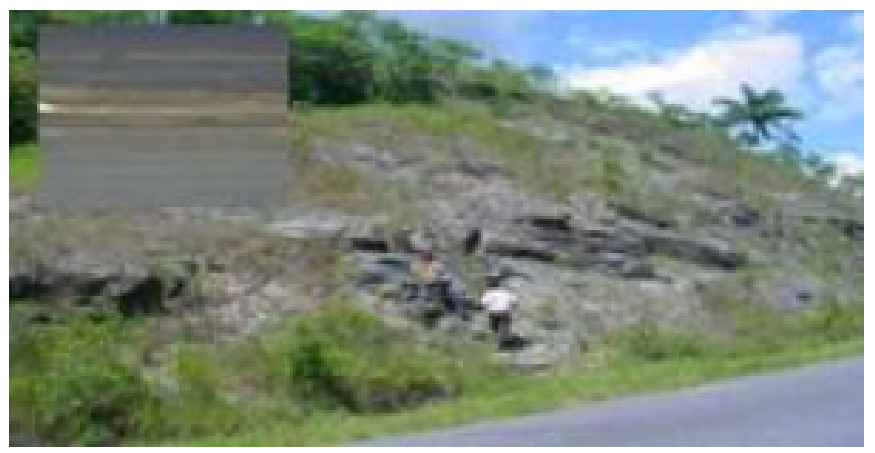

Fig. (7). Formación Peñalver sandstone Quarry. One of the best outcrop of $\mathrm{K} / \mathrm{T}$ limit in Cuba.

\section{GEDA CAVE NATIONAL MONUMENT GEOLOGICAL AND PALEONTOLOGICAL SITE ACCESS ONLY FOR SCIENTIFIC PURPOSES DO NOT ENTER WITHOUT PERMISSION. PROTECT IT}

\section{Havana Province}

The holostratotype of the Martin Mesa formation and Cueva del Bicho (Vermin Cave) -where the bigger Cuban Myliobatidae has been found, in Ceiba del Agua, Caimito municipality-are proposed as Local Monuments [7].

The following geosites are proposed to be designated National Monuments: Sinkhole and cave in Loma Candela, Cueva de Paredones in Caimito municipality, and Cueva del Túnel in Quivicán municipality.

\section{Cueva de Paredones (Cliffs Cave) Geosite}

Cueva de Paredones is in the bottom of a sinkhole that was formed in limestone of the Güines formation, next to the Ceiba del Agua-Alquizar road, to the south of Antonio Maceo neighborhood, near the Revolutionary Armed Forces Academy of same name.

Since the $19^{\text {th }}$ century, bat guano was extracted by means of a scaffold placed in a natural skylight approximately midway through the cave route, which is about $600 \mathrm{~m}$ long. Black slaves were used to carry out this work, and they carved the stalagmites in the chamber where the scaffold lies, as a gift to their African gods.

Also in this chamber, a nearly 20 -meter-deep well was drilled; this well -together with the extracted guano- should have contributed the first fossil remains, which were lost.
In the 1950s, the Cuban Speleological Society, which was developing intensive work in researching Cuban caves, knew about that site and took care of the pieces of research whereby fossil remains of the fauna that used to live in the Cuban archipelago were found. In the period between 1954 and 1975, Oscar Arredondo -the most distinguished and knowledgeable Cuban paleontologist of that time- and his collaborators identified, for the first time, the following species in this geosite: Pulsatrix arredondoi, Ornimegalonix minor, Antillovultur varonai, Burhinus sp., Gymnoglaux sp., Tyto alba spp., they all are extinct bird species (eagles, owls, etc), which were much bigger than the current species of their kind-such as Antillovultur, which was bigger that the Andean condor- and were most surely the predators of the numerous Quaternary herbivorous fauna. Likewise, this cave has contributed remains of Ara tricolor (or cubensis), the Cuban macaw, which became extinct in more recent times.

Besides, Cueva de Paredones is the type site of species that, when found, were new to science such as Solenodon arredondoi (a Cuban solenodon species), Mesocapromys kraglievichi (a hutia species ${ }^{5}$ ), Neomesocnus brevirrostris and Habanocnus hofstetteri (sloth species).

Together with these remains, bone fragments of sloths have been and are still found: Megalocnus rodens, Mesocnus torrei, Mesocnus browni; rodents such as Capromys pleistocenicus, and others that are common, such as Capromys pilorides; insectivores such as Solenodon cubanus; shrews like Nesophontes micrus, N. major and other typical examples of Cuban Quaternary fauna [8].

Prospectively, the site can contribute much more about Quaternary life.

In spite of scientific research, the cave was successfully used, for a while, to grow edible mushrooms. The attempt to increase mushroom production resulted in disturbed weather conditions, and the plantation failed (Fig. 8).

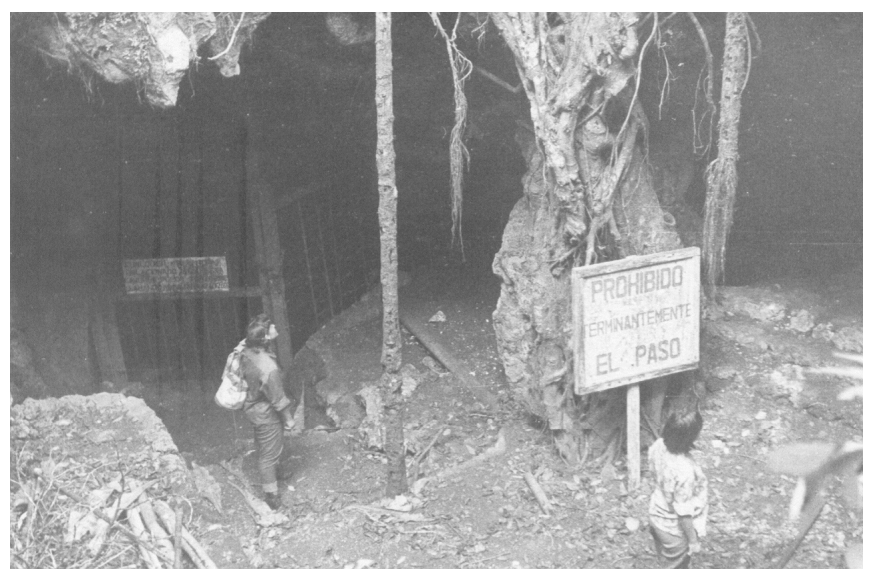

Fig. (8). Cueva de Paredones. The more important fossil deposit in Cuba with more than 7 new species.

This site currently falls within the boundaries of a farm belonging to the Menelao Mora Enterprise of the Agricultural and Livestock Union of the Revolutionary Armed Forces (FAR), and accessing it depends on the decision of the director of said entity. There is an accesspreventing metal gate at the cave entrance and the floor has

\footnotetext{
${ }^{5}$ A rodent with more than 11 living and fossil species
} 
been covered with gravel layers. Access passages are practically covered with vegetation, and trails leading to the cave are blocked by plants. The geosite is category A, with 93 points.

Due to its scientific importance, the authors have thought it convenient to make the following proposals: to the National Heritage Commission, that this site be declared National Heritage; to the Ministry of Science, Technology and Environment, that the site be preserved for future paleontological research and its access be restricted only to duly authorized researchers; and to the local government, that the site be signposted, protected and conserved.
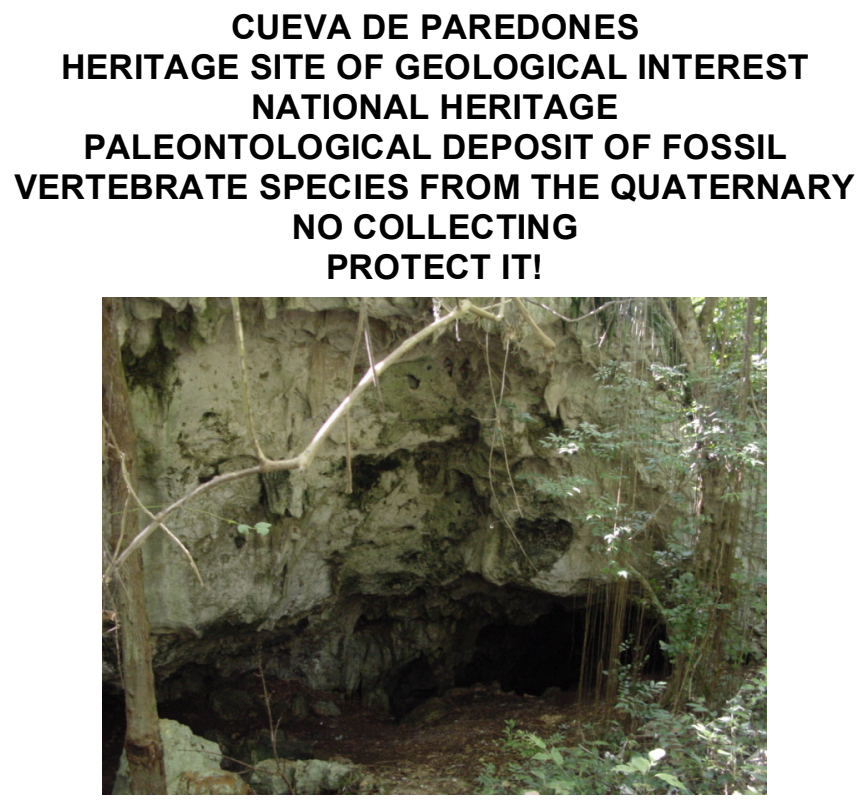

\section{Havana City Province}

The holostratotype of La Trampa formation and Salomón Mine to the east of the province are proposed as Local Monuments, and the holostratotype of Peñalver formation is proposed as National Monument.

\section{Holostratotype of Peñalver Formation}

This stratotype described in 1963 [9] is in a wide outcrop along the Monumental highway, approximately $1 \mathrm{~km}$ west from Peñalver village, Havana City province.

The diagnosis lithology is represented by a clasticcalcareous sequence varying from thick-grained gravelites (lower part) to thin-grained calilutites (higher part). The clastic material is mostly carbonate and organogenic and, to a lesser degree, igneous. In the mid-part of the outcrop, in the calcarenite layers, in some places, there are some oriented fragments of carbonaceous material.

The geosite is of a high scientific value, since it represents a K-T-boundary-marking geological unit related to the cosmic collision that occurred 65 million years ago, so it is represented by the paleontological cocktail of the Cretaceous-Tertiary boundary (KTB) made up of fossil assemblages of different Cretaceous ages (Maastrichtian, Campanian, Coniacian-Santonian, Huronian, Albanian, Cenomanian, Apian). The youngest fossils correspond to upper Maastrichtian. Badly preserved microfossil remains from the Paleocene have been reported.

This lithostratigraphic unit has developed in Havana City, Havana, Matanzas and Pinar del Río provinces and is further divided into 5 members [10]: basal, lower, medium, higher, and highest member.

Its discordant deposition on a Via Blanca formation can be clearly observed in this outcrop.

According to the established patterns, it reaches the category of geosite class A (94 points). Due to its great scientific value, easy access and vulnerability, the authors propose this site to be declared National Monument and access to its entrance to be conveniently restricted, which can be done by way of the following sign:

\section{NATIONAL MONUMENT \\ HERITAGE SITE OF GEOLOGICAL AND \\ PALEONTOLOGICAL INTEREST PEÑALVER FORMATION REPRESENTATIVE OF THE CRETACEOUS-TERTIARY BOUNDARY PROTECT IT!}

\section{¡PROTEJALO!}

\section{Isle of Youth Special Municipality}

This territory comprises two different regions: the North, with metamorphic rocks [11] and an old history of mining exploitation of marble, construction stone and feldspar quarries for the ceramic industry and a gold mine; and the southern region, with a less disturbed, Pliocene-Pleistocene cover of carbonate rocks [12].

The holostratotype of Cocodrilo formation is proposed as a Local Monument.

\section{Cocodrilo Formation, Holostratotype}

The geosite is in the coastal cliff next to Cocodrilo village in the southern island and is composed of fine, highly stratified, white and sometimes rose-shaded calcarenites that, when weathered, have turned gray. There is crossstratification in some sections.

There is no visible marine fauna in the calcarenite layers; though there are remains of corals and mollusks in the beach of sand and boulders surrounding the outcrop. By sections, the sandstone is covered with a hard, calcrete-type, reddish crust.

The action of abrasion and karstic corrosion has isolated pieces of cliff as stratum packages.

There is very pointed karren on the surface, and up-to-56-m-high tidal niches have developed in the cliff [13] (Fig. 9).

It scored 90 points in the diagnosis, which make it rank as category A. It is proposed to be protected by means of having the area demarcated and the site declared Local Heritage. 


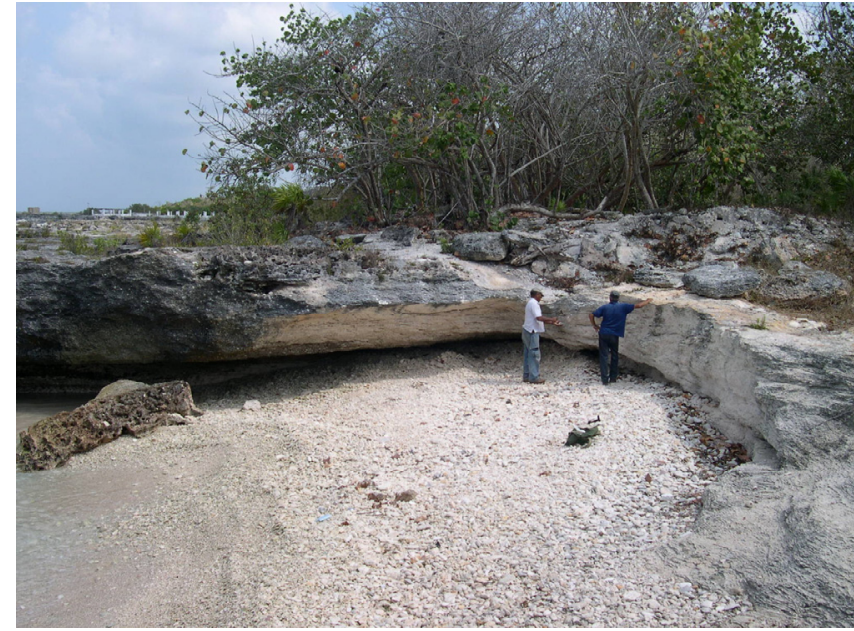

Fig. (9). Type locality of Cocodrilo Formation, in the karstic south of Island of Youth.

A sign for the geosite will read:

\section{COCODRILO FORMATION HOLOSTRATOTYPE LOCAL HERITAGE PROTECT IT}

\section{REFERENCES}

[1] R.G. Domech, C. Díaz, A. Barrientos, and E. Balado, "Proposed methodology to be used for actions aimed at protecting and conserving the geological heritage", Proceedings of the 2 a Earth Sciences Convention, 2007, ISBN 978-959-7117-16-2.

[2] R.G. Domech, A.B. Duarte, E.B. Piedra, L. Flores, G. Furrazola, and G. Pantaleón, "Remarks on geological heritage preservation in Havana province", Proceedings of the $2 a$ Earth Sciences Convention, 2007, ISBN 978-959-7117-16-2.
[3] A.B. Duarte, M.R. Gutiérrez, and M. Roberto Gutiérrez y Gustavo Furrazola, "Catalog of sites of geological and paleontological interest in Havana provinces", Proceedings of the It Earth Sciences Convention, 2005, ISBN 959-7117-03-7.

[4] M.R.G. Domech, L.B. Rodríguez, A.B. Duarte, A.I.L. Castro, N.L. Rodríguez, L.F.V.G.P. Vento, E. B. Piedra, J.L.C. Porras, Y.M. Maqueira, and J.Z. Martín, "Geological heritage of Pinar del Río Province", Proceedings III Earth Sciences Convention, 2009, ISBN 978-959-7117-19-3.

[5] M.R.G. Domech, L.B. Rodríguez, J.T.C. Gómez, A.B. Duarte, A.I.L. Castro, and G.F. Bermúdez, "Remarks on the geological heritage of the Isle of Youth", Proceedings III Earth Sciences Convention, 2009, ISBN 978-959-7117-19-3.

[6] M. Acevedo, and R. Gutiérrez, "The Majaguas-Cantera cave system, Pinar del Río Cuba," Bulletin of the Venezuelan Speleology Society", vol. 5, no. 10, pp. 125-142, 1974.

[7] M. Iturralde, M.C.L. Mora, R. Rojas, and M.R. Gutiérrez, "Myliobatidae (Elasmobranchii: Batomorphii) of the Cuban Tertiary", Mexican Paleontological Society Revue, vol. 8, no. 2, pp. $135-145,1998$

[8] A. Carlos, "Geographic distribution of Mammal Remains (Edentata: Megalonychidae) of the Cuban Tertiary and Quaternary", Sciences, ser. 4, no. 8, 1994.

[9] P. Bronnimanand, and D. Rigassi, "Contribution to the geology and paleontology of the area of the city of La Habana, Cuba and its surroundings", Eclogae Geologicae Helvetiae, vol. 5, no. 1, pp. 193-480, 1963

[10] C. D. Otero, G. Furrazola, D. García, E. Linares, R. Gutiérrez, and S. Gil, "Stratigraphic Lexicon of Cuba", La Habana, Institute of Geology and Paleontology (inédito), 2002, pp. 355.

[11] M. Guillermo, "Geology of the Metamorphic Massif in the Isle of Youth", Sciences of the Earth and the Space, Academy of Sciences of Cuba, La Habana, vol. 3, pp. 3-22, 1981.

[12] L. Leandro, P.R. Batista, and L. Rodríguez, "Carbonate rocks of Western Cuban Quaternary. Exploitation and Environment", Proceedings of the 2a Earth Sciences Convention, 2007, ISBN 978-959-7117-16-2.

[13] A.N. Jiménez, A. Panos, and V.O. Stelcl, "The Tropical Karst in the Isle of Pines", Speleológic and Karst Series, La Habana, vol. 34, pp. 35, 1972.

(C) M. Roberto Gutiérrez Domech; Licensee Bentham Open.

This is an open access article licensed under the terms of the Creative Commons Attribution Non-Commercial License (http: //creativecommons.org/licenses/by-nc/ 3.0/) which permits unrestricted, non-commercial use, distribution and reproduction in any medium, provided the work is properly cited. 